\title{
Pandemic Risk and International Law
}

\author{
Laying the Foundations for Proactive State Obligations
}

\author{
Pedro A. Villarreal*
}

\section{Introduction**}

Under existing instruments of international law, the origins of pandemics as such fall beyond states' obligations, being considered to be inevitable. Thus, there is an absence of primary law obligations leading to responsibility for the outbreak of a pandemic per se. Instead, the World Health Organization (WHO)'s International Health Regulations (IHR) of 2005, the legally binding instrument in the area, currently enshrines a reactive approach on the basis of surveillance mechanisms aimed at fostering a rapid response in case a pandemic emerges. ${ }^{1}$ So far, the international community has yet to formulate a legally binding framework designed to comprehensively address the drivers of pandemic risk in particular.

Epidemiological public health research increasingly shows how human activity is a major determinant of pandemic risk. ${ }^{2}$ In terms of their origins, the human - (non-human) animal - environment interface stands at the core of pandemics. The One Health perspective has emerged as a more holistic

* Senior Research Fellow, Max Planck Institute for Comparative Public Law and International Law, Heidelberg, Germany.

** The author would like to thank the editors of the Yearbook for their biblical patience, as well as the anonymous peer reviewers for thorough revision and in-depth feedback. Special thanks to Lisa Herrmann for research assistance. The author is also grateful to the Max Planck Institute for Comparative Public Law and International Law and its Director, Armin von Bogdandy, for making the current Open Access publication possible.

1 David Fidler, 'From International Sanitary Conventions to Global Health Security: The New International Health Regulations' (2005) 4 Chinese Journal of International Law, 325; Lawrence Gostin and Rebecca Katz, 'The International Health Regulations: The Governing Framework for Global Health Security' (2016) 94 The Milbank Quarterly, 264; Gian Luca Burci and Mark Eccleston-Turner, 'Preparing for the Next Pandemic: the International Health Regulations and World Health Organization during COVID-19' (2019) 2 Yearbook of International Disaster Law, 261; This approach was recently criticised by the Independent Panel on Pandemic Preparedness and Response, 'COVID-19: Make it the Last Pandemic' (May 2021) <https://theindependentpanel.org/mainreport/> last accessed (as any subsequent URL) on o1 August 2021.

2 Rory Gibb et al., 'Zoonotic host diversity increases in human-dominated ecosystems' (2020) 584 Nature, 398. 
approach to address the multidimensional setting. ${ }^{3}$ But, so far, de lege ferenda debates on how states' acts and omissions should be regulated in the area remain work in progress. Against this backdrop, the following sections discuss potential ways to construe future international law obligations of pandemic risk reduction, a term broadly understood to include the regulation of activities directly linked to the emergence and re-emergence of pathogens with a potential to create pandemics. Beyond the contingent question of whether there will exist sufficient state consensus in the subject, this article posits some analytical steps that could help steer future discussions.

In contrast to the IHR (2005), the current analysis deals with how events leading to the emergence of a pandemic disease could be regulated under international law. Therefore, the type of risk addressed in the following lines is not only the one related to the consequences of pandemics and a rapid response thereto, but rather those pertaining to their origins. As the article argues, if the looking glass of pandemic risk is employed, there is a fragmented set of legally binding norms in place. The present analysis heavily builds upon the notion of 'deep prevention' fostered by Jorge Viñuales, Suerie Moon, Ginevra Le Moli and Gian Luca Burci. ${ }^{4}$ In their view, any future legal instrument in the field of pandemics should aim at a more ambitious regulation of the drivers of outbreaks, with a strong emphasis on those that may trigger a zoonotic event, ${ }^{5}$ i.e. when a pathogen present in non-human species crosses the interspecies barrier and infects humans. ${ }^{6}$

Any future regulation of pandemic risk prevention would have to, first, establish whether and to what extent pandemics will be considered to be influenced by human activity; and, second, whether states' specific actions or omissions in the prevention of pandemic risk could be framed as international law obligations, and in what terms. The article proceeds by highlighting some of the epistemic gaps that may explain why existing international norms have, so far, not tackled pandemics as possibly manmade events. Similar to the evolution

3 wHO, World Health Assembly Resolution WHA74.7, 'Strengthening wHO preparedness for and response to health emergencies' (31 May 2021); see also Stefania Negri and Mark Eccleston-Turner, 'One Health and Pathogen Sharing: Filling the Gap in the International Health Regulations to Strengthen Global Pandemic Preparedness and Response', International Organizations Law Review (forthcoming 2022).

4 Jorge Viñuales, Suerie Moon, Ginevra Le Moli and Gian Luca Burci, 'A global pandemic treaty should aim for deep prevention' (2021) 397 The Lancet, 1791, 1791-1792.

5 Ibid.

6 wHO, 'Zoonoses' (29 July 2020) <https://www.who.int/news-room/fact-sheets/detail/ zoonoses>. 
of risk reduction under international disaster law in recent decades, ${ }^{7}$ the text shows what a shift from a predominantly reactive approach towards a proactive one would entail. Second, the following text looks at how risk reduction is regulated in international law more broadly, revisiting the distinction between natural and manmade threats as a basis for specific regulatory choices. Third, the text sets some basic foundations for what overcoming the current reactive approach towards pandemic risk would legally entail. It is a particularly apposite subject in light of ongoing discussions of a new international instrument on pandemic preparedness and response, ${ }^{8}$ which at the moment of writing is subject to an uncertain process of high-level negotiations and debates. Lastly, the text puts forward conclusions on how the analysis herein can contribute to legally framing future steps towards the effective regulation of pandemic risks, a matter highly dependent on resorting to the state of the art in the medical and life sciences.

The current contribution focuses on pandemic risks. This delineation already leads to a major epistemic gap, as there is as yet no legally enshrined definition of 'pandemic'. ${ }^{9}$ Instead, the existing operational term is a 'public health emergency of international concern', currently foreseen and defined by Article 1 I H R (2005). ${ }^{10}$ The latter is a wider term encompassing non-pandemic outbreaks. ${ }^{11}$ Both share multiple elements, such as being 'extraordinary events' ${ }^{12}$ and referring to communicable diseases in so far as it focuses on their transmission

7 Jacqueline Peel and David Fisher, 'International Law and the Intersection of Environmental Protection and Disaster Risk Reduction' in Jacqueline Peel and David Fisher (eds), The Role of International Environmental Law in Disaster Risk Reduction (Brill Nijhoff 2016) 7 . World Health Assembly, 'Special session of the World Health Assembly to consider developing a wHо convention, agreement or other international instrument on pandemic preparedness and response' (31 May 2021) WHA74(16).

9 Pedro A. Villarreal, 'Pandemic: Building a Legal Concept for the Future' (2021) 20 Washington University Law Global Studies Law Review, 611, 611-626.

10 Article 1 IHR (2005) defines a public health emergency of international concern as 'an extraordinary event which is determined (...) to constitute a public health risk to other States through the international spread of disease and (...) to potentially require a coordinated international response'.

11 Villarreal (n 9).

12 Though not all accept this extraordinary nature, arguing it excludes other diseases with a high burden of disease globally. 
across territorial borders. ${ }^{13}$ Consequently, for analytical purposes, the understanding of 'pandemic risk' employed in the current article is a broad one, referring generally to diseases with a potential for a cross-border spread. Therefore, the type of events alluded in this text's understanding of pandemic risk overlap with the definition of a public health emergency of international concern. Ultimately, all pandemic events caused by novel or re-emerging pathogens begin with a localized outbreak, as the first point of infection can be traced back to a specific location. ${ }^{14}$ There is a pending clarification on whether there can be thresholds to determine when a disease has acquired a pandemic status by being "global". In the past, the wHo developed fixed geographical criteria, by considering that a pandemic - or, more precisely, the maximum level of pandemic alert - occurred when a novel disease was present in at least two of the organisation's different regions. ${ }^{15}$ After criticisms levelled against this approach and its consequences during the H1N1 influenza pandemic of $2009,{ }^{16}$ the geographical yardstick was later abandoned in favour of more open-ended and vague terms such as 'global spread'. As a result, no threshold for determining the exact geographical scope of a pandemic exists to this day. Such lack of precision will inevitably affect efforts at risk reduction.

Similar to how disasters are considered to be such depending on whether they affect human interests or pose a threat of doing so, ${ }^{17}$ the concept of a 'novel disease' for the purposes of pandemic risk reduction is human-centric. As explained below, a vast number of these pathogens are circulating in nature. Whether they trigger epidemics or pandemics is a factor contingent upon their circulation amongst humans. ${ }^{18}$ Here lies an epistemic gap, in so far as targeting diseases once they are present in human hosts may be too late for the purposes

13 The term 'communicable diseases' is not a legal one, but rather stems from the medical and epidemiological fields. See Institut de Droit International, 12th Commission, 'Epidemics and International Law' (August 2021) para. 35 .

14 David Morens, Gregory Folkers and Anthony Fauci, 'What Is a Pandemic?' (2009) 200 The Journal of Infectious Diseases, 1019.

15 WHO, 'Pandemic Influenza Preparedness and Response. A WHO Guidance Document' (2010) 27 .

16 Sudeepa Abeysinghe, Pandemics, Science and Policy. HıNı and the World Health Organization (Palgrave MacMillan 2015) 64-83.

17 The ILC's definition of 'disasters' includes those that cause environmental damage, in so far as it constitutes humans' living space. Giulio Bartolini, 'A Taxonomy of Disasters in International Law' in Flavia Zorzi Giustiniani, Emanuele Sommario, Federico Casolari and Giulio Bartolini (eds) Routledge Handbook of Human Rights and Disasters (Routledge 2018) 16-19.

18 Following the definition by David Morens, Gregory Folkers and Anthony Fauci, 'The challenge of emerging and re-emerging infectious diseases' (2004) 430 Nature 242, 242-243. 
of prevention. More scientific insights are needed focusing on the countless interactions preceding a zoonotic event.

In past decades, mankind has witnessed how communicable diseases may be removed altogether from circulation across human and even (non-human) animals: both smallpox ${ }^{19}$ and Rinderpest ${ }^{20}$ - a viral disease affecting cattle were officially declared as eradicated. But normative goals consisting of the elimination of all risks stemming from communicable diseases are not feasible. Under the current stage of research in virology and immunology, new and re-emerging pathogens will remain a possibility. ${ }^{21}$ Choosing the most effective mechanisms to reduce pandemic risk will depend to a large extent on insights from the fields of medicine, epidemiology and public health. But there are existing gaps in these fields of knowledge on how to assess pandemic risk, since the latter involves a probabilistic estimation of an adverse outcome, ${ }^{22}$ i.e. one that may or may not occur given a series of suppositions. This consideration inevitably spills over to the legal domain and curbs attempts at comprehensive regulation. The epistemic gap is closely related to the ubiquitous nature of pandemic threats. Although the precautionary principle aims at addressing issues where scientific knowledge on a specific risk is deemed to be inconclusive, ${ }^{23}$ it does not provide a regulatory basis for acts and omissions by states to prevent pandemics. In turn, the limited knowledge on how many activities ought to be regulated internationally, and in which priority, is one of the determinants of the legal lacuna in pandemic risk prevention.

Throughout the last decades, the global health literature has underscored how the accelerating process of globalization, due to the increased movement of goods and persons across borders, increases pandemic risks. ${ }^{24}$ Owing to this

19 Officially declared to be eradicated in 1979. See wHo, 'The Global Eradication of Smallpox. Final Report of the Global Commission for the Certification of Smallpox Eradication' (1980).

20 Declared to be eradicated from cattle by the FAO and the World Organization for Animal Health in 2011. Peter Roeder, Jeffrey Mariner and Richard Kock, 'Rinderpest: the veterinary perspective on eradication' (2013) 368 Philosophical Transactions of the Royal Society, 1.

21 David Heymann et al., 'Global health security: the wider lessons from the west African Ebola virus disease epidemic' (2015) 385 The Lancet, 1884, 1887.

22 On this definition of risk assessments as applied to public health, see Gilbert Omenn and Elaine Faustman, 'Risk assessment and risk management', in Roger Detels, James McEwen, Robert Beaglehole and Heizo Tanaka (eds), Oxford Textbook of Public Health (OUP 2004 ${ }^{4}$ ) 1084-1085.

23 On the competition between the precautionary principle and the 'sound science' approach as epistemic paradigms for decision-making, see Jacqueline Peel, Science and Risk Regulation in International Law (CUP 2010) 111-170.

24 David Fidler, International Law and Infectious Diseases (oup 1999) 5; Benjamin Mason Meier, 'Employing Health Rights for Global Justice: The Promise of Public Health in 
process, pathogens can now spread faster through different countries. While travel and trade are by no means the sole trigger of the global spread of diseases, they nevertheless constitute core drivers thereof. ${ }^{25}$ Perhaps due to an understanding of international travel and trade as inevitable - and, under some accounts, even desirable ${ }^{26}$ - international law norms cannot operate on the basis that they might be proscribed in order to fully stem cross-border health hazards. A full global "lockdown" would actually run counter to the multilateral dimension that international law purports to achieve and consolidate. ${ }^{27}$ In fact, the first attempts at the international regulation of pandemics in the XIX Century attempted to both protect the populations of European countries against "exotic" diseases spreading from abroad while preserving the ability to conduct trade and travel abroad. ${ }^{28}$ The threat of scaling down international travel and trade creates major disincentives for the fulfilment of the goals of global health security, namely fostering an effective global epidemiological surveillance through the prompt and accurate notification by states of diseaserelated events. ${ }^{29}$

The object and purpose of the IHR (2005) is precisely to balance the goals of fostering health security by preventing, protecting and responding to the cross-border spread of diseases, on the one hand, while avoiding 'unnecessary interference with international traffic and trade', on the other hand. ${ }^{30}$ The dichotomy does not mean that the two goals are always at odds, but rather that legal solutions are needed for instances where they are. Although the IHR (2005) represents an integrated approach that acknowledges the

Response to the Insalubrious Ramifications of Globalization' (2006) 39/3 Cornell International Law Journal, 716-717; Kelley Lee, 'Globalization', in Roger Detels, Martin Gulliford, Quarraisha Abdool Karim and Chorh Chuan Tan (eds), Oxford Textbook of Public Health (ouP 2015 ${ }^{6}$ ) 62-78.

25 UNEP/International Livestock Research Institute, 'Preventing the Next Pandemic. Zoonotic disease and how to break the chain of transmission' (Nairobi 2020) $15^{-17}<$ https://wedocs .unep.org/bitstream/handle/20.500.11822/32316/ZP.pdf?sequence=1\&isAllowed=y >.

26 Roojin Habibi et al., 'Stop Violating the International Health Regulations' (2020) 395 The Lancet, 664 .

27 On the 'welding of states' as one of the central underpinnings of international law, see Stephen Neff, 'A Short History of International Law' in Malcolm Evans (ed) International Law (OUP 20185) 22.

28 Hélène de Pooter, Le droit international face aux pandémies: vers un système de sécurité sanitaire collective? (Editions A. Pedone 2015) 30-31.

29 As enshrined mainly in Article 6 IHR (2005). Adam Kamradt-Scott, 'WHO's to blame? The World Health Organization and the 2014 Ebola outbreak in West Africa' (2016) 37 Third World Quarterly, 411.

Article 2 IHR (2005). 
interdependence between public health, trade and travel, ${ }^{31}$ striking the right balance in settings where the different objectives may be in tension requires a case-by-base analysis. ${ }^{32}$ The balancing exercise in harmonising the IHR (2005)'s different objectives depends on available epidemiological data. Major challenges emerge when it cannot be known, on the basis of existing information, whether the outbreak of a new and highly contagious pathogen can be fully contained in one geographical location, or if delaying its course would be a more reasonable course of action. The assessment will depend on the disease at hand. For instance, a report issued by a wHO IH R Review Committee on the 2009-2010 H1N1 influenza pandemic underscored how, due to the features of the disease, 'rapid containment (...) was never really feasible', hence mitigation measures to manage the impact of the virus' spread were a better option. ${ }^{33}$ This was despite the fact that, according to the Review Committee's report and on the basis of available records, the surveillance system enshrined in the IHR (2005) based on prompt notification by States Parties functioned well. ${ }^{34}$ Conversely, the Ebola virus that ravaged West Africa did not turn into a pandemic, since the disease could be effectively contained in countries other than the three most affected ones, ${ }^{35}$ i.e. Guinea, Liberia and Sierra Leone. ${ }^{36}$ One of the key determinants for its cross-border spread was deficient healthcare

31 Especially in comparison to its predecessors, the International Sanitary Regulations of 1951 and the IHR (1969). See Fidler (n 1) 386-387.

32 This explains the flexibilities allowed for in Article 43 IHR (2005). See Roojin Habibi et al., 'The Stellenbosch Consensus on Legal National Responses to Public Health Risks: Clarifying Article 43 of the International Health Regulations', International Organizations Law Review (forthcoming).

33 wно, 'Strengthening Response to Pandemics and Other Public-Health Emergencies. Report of the Review Committee on the Functioning of the International Health Regulations (2005) and on Pandemic Influenza (HiNi) 2009' (France, 1 January 2011) xvi, 32-33.

34 Ibid., 54.

35 These countries were Nigeria, Spain, Mali, Senegal, the United Kingdom and the United States of America. See wHO, 'Ebola Situation Report - 3o March 2016', <https://apps.who .int/ebola/current-situation/ebola-situation-report-3o-march-2016>.

$3^{6}$ In these three countries, it took a total of twenty-four months between the proposed origin in the province of Guéckédou, Guinea and the containment of the last cluster of Ebola transmission in Liberia. The delayed response in these three countries is believed to be directly correlated with insufficient healthcare capacities. WHO, 'Report of the Review Committee on the Role of the International Health Regulations (2005) in the Ebola Outbreak and Response' (13 May 2016) A69/21, para. 42; David Heymann et al., 'Global health security: the wider lessons from the west African Ebola virus disease epidemic' (2015) 385 The Lancet, 1888. 
capacities in the most impacted states, shedding light on the limitations of the IHR (2005)'s obligations to enhance minimum core capacities. ${ }^{37}$

Pandemic risks are embedded in a complex and multifactorial interface in which numerous human activities may trigger disease outbreaks. The interface between human and (non-human) animals, in particular, is a central component of pandemic risks. According to data from the WHO, zoonoses constitute approximately $75 \%$ of emerging diseases ${ }^{38}$ - though this number is not a fixed one. There is evidence zoonoses have been at the helm of three of the most recent high-profile disease outbreaks, the H1N1 influenza pandemic in 2009, the West African Ebola crisis in 2014, and possibly COVID-19 in late 2019. In the case of H1N1 influenza, the virus was traced back to a pig farm in Mexico, hence the colloquial term "swine flu". ${ }^{39}$ By contrast, the 2014 West African Ebola crisis is believed to have begun when a small child was playing with a wild animal in a rural area in December, 2013. ${ }^{40}$ Actions like this one, devoid of any purposeful goal such as fostering knowledge or pursuing economic benefit, could hardly be proscribed under international law. Such complexity is precisely what fosters the impossibility to tackle every single one of these activities in a manner that prevents any and all contacts between human and (non-human) animals in order to avoid so-called 'zoonotic spillover'.

At the moment of writing, the evidence on the origins of COVID-19 is inconclusive. ${ }^{41}$ It stands at the core of ongoing geopolitical tensions between China and other countries such as the United States and Australia. ${ }^{42}$ Recent reports by an inspection team deployed by the wHO and presented at the 74th World Health Assembly offered a list of possibilities. ${ }^{43}$ The final verdict

37 As enshrined in Article 5 IHR (2005). See also Katz and Gostin (n 1); Giulio Bartolini, 'The Failure of "Core Capacities" under the wHo International Health Regulations' (2020) 70 International \& Comparative Law Quarterly, 233, 233-25o.

38 wHO, 'Zoonoses' (29 July 2020) <https://www.who.int/news-room/fact-sheets/detail/ zoonoses $>$.

39 See who, 'Strengthening Response to Pandemics' (n 33).

40 As stated in the chronology set in wHo, 'Report of the Review Committee on the Functioning of the International Health Regulations (2005) during the coviD-19 response' (30 April 2021) A74/9 Add.1, paras. 42-52, <https://cdn.who.int/media/docs/default -source/documents/emergencies/a74_9add1-en.pdf?sfvrsn=d5d22fdf_1\&download $=$ true $>$.

Amy Maxmen, 'US COVID origins report: researchers pleased with scientific approach' (Nature News, 27 August 2021) <https://www.nature.com/articles/d41586-o21-02366-o>. On geopolitical tensions due to disagreements on the origins of CoviD-19, see Amy Maxmen, 'Divisive COVID "lab leak" debate prompts dire warnings from researchers' (Nature News, 27 May 2021) <https://www.nature.com/articles/d41586-o21-01383-3>.

43 WHO, 'Report of the Review Committee on the Functioning of the International Health Regulations (2005) during the COVID-19 response (2021)', para. $5^{\circ}<$ cdn.who.int/media/ 
on how COVID-19 emerged in humans is still due. ${ }^{44}$ Nevertheless, the hypotheses considered to be the likeliest heavily lean towards a zoonotic infection, i.e. one where a (non-human) animal host transmitted the SARs-CoV-2 virus to a human. ${ }^{45}$ Even the controversial claims of a laboratory-based event ${ }^{46}$ point to zoonosis as the likeliest explanation of how a human first became infected with said pathogen.

Considering the epistemic challenges described above, the international regulation of pandemic risk can operate in a two-tiered dimension:1) to reduce the likelihood of the first human infection with a novel or re-emerging disease, which would fall in line with the 'deep prevention' approach; and, 2) to prevent outbreaks from evolving into a more serious threat. The recent report by the Independent Panel on Pandemic Preparedness and Response seems to advocate the second approach. ${ }^{47}$ Nevertheless, envisaging a proactive international law regime that tackles the origins of pandemics is a worthwhile endeavour.

Taking the epistemic gaps into account, instead of aiming for full elimination as a goal, ${ }^{48}$ a viable alternative is the regulation of human actions - and, more ambitiously, omissions - that are known to "maximise" the probability of a pandemic event occurring. The goal can be two-pronged: to create obligations aimed at preventing either disease outbreaks from occurring at all, or those acts that accelerate the consequences thereof. ${ }^{49}$ There is a growing consensus in epidemiology and public health of how pandemic risks are, at least

docs/default-source/documents/emergencies/a74_9add1-en.pdf?sfvrsn=d5d22fdf_1\& download=true $>$ Independent Panel for Pandemic Preparedness and Response (n 1 ).

44 After the first inconclusive report by the inspection team deployed to Wuhan, China, the wHO recently announced the creation of an International Scientific Advisory Group for Origins of Novel Pathogens (SAGO). See United Nations, 'UN health agency urges support for new COVID-19 origins studies' (UN News, 13 August 2021) <https://news.un.org/en/ story/2021/08/1097732>.

45 Four hypotheses of the origins of COviD-19 were posited at 'WHO-convened Global Study of Origins of SARS-CoV-2: China Part. Joint wHO-China Study', Joint Report (30 March 2021) 111.120, <https://www.who.int/docs/default-source/coronaviruse/final -joint-report_origins-studies-6-april-201.pdf?sfvrsn=4f5e5196_1\&download=true $>$.

46 Nicholas Wade, 'The origin of COVID: Did people or nature open Pandora's box at Wuhan?', Bulletin of the Atomic Scientists (5 May 2021) <https://thebulletin.org/2021/o5/ the-origin-of-covid-did-people-or-nature-open-pandoras-box-at-wuhan/>; for a more nuanced perspective cross-referencing several sources, see Amy Maxmen and Smriti Mallapaty, 'The COVID lab-leak hypothesis: what scientists do and don't know' (Nature News, o8 June 2021) <https://www.nature.com/articles/d41586-o21-01529-3>.

47 Independent Panel for Pandemic Preparedness and Response (n 1 ) 6o.

48 On China's strategy of full elimination of the SARs-CoV-2 virus, see Philipp Renninger, 'The "People's Total War on COVID-19": Urban Pandemic Management Through (Non-) Law in Wuhan, China' (2020) 30 Washington International Law Journal, 63, 63-115.

See Independent Panel on Pandemic Preparedness and Response (n 1) 36-37, 45 . 
partially, manmade. Human encroachment into ecosystems where they have historically been absent leads to an increased contact with all types of pathogens, some of which, in turn, are deadly for humans. ${ }^{50}$ Hence, in virology the tripartite distinction between humans, (non-human) animals and the environment is known to be an artificial one..$^{51}$ Under a more holistic perspective, an approach capable of looking beyond the anthropocentric focus is needed.

In general terms, the evidence so far on the degree of human activities enhancing pandemic risks is less developed than the equivalent research on, for example, climate change in the environmental field. Indeed, perhaps one of the most decisive turning points for climate change law was the realization, through comprehensive empirical data, that human activities are accelerating it. ${ }^{2}$ Furthermore, environmental impact assessments (EIAs) gauging the risk of a harm caused by specific human activities are, by now, part and parcel of the no-harm rule under customary international law. ${ }^{53}$ Whereas states are obliged to conduct EIAs in the case of major infrastructure projects, ${ }^{54}$ several authors have argued they are insufficient to truly tackle the major sources of environmental risk, namely those with a global dimension. ${ }^{55}$ In a similar vein, health impact assessments are available and are conducted in certain countries to evaluate the impact of certain policies in the health of a population. ${ }^{56}$ Two major limitations of these type of assessments have been pointed out elsewhere. First, owing to the diversity of health impacts and the complex causal chains they involve, their effectiveness is not equally calibrated. ${ }^{57}$ Second, country usage of health impact assessments is not as widespread as EIAs. ${ }^{58}$ Similarly, in the field of epidemiology, studies of so-called 'disease hot

50 See Gibb et al. (n 2).

$5^{1} \quad$ Linfa Wang and Gary Cramieri, 'Emerging zoonotic viral diseases' (2014) 33 Revue Scientifique et Technique-Office international des épizooties, 569, 569-577.

52 Floor Fleurke, 'Catastrophic Climate Change, Precaution, and the Risk/Risk Dilemma' in Mónika Ambrus, Rosemary Rayfuse and Wouter Werner (eds), Risk and the Regulation of Uncertainty in International Law (Oxford University Press 2017) 201.

53 ICJ, Certain Activities Carried Out by Nicaragua in the Border Area (Costa Ricav Nicaragua) (Merits) [2015] ICJ Rep 2015, para. 104.

54 For a recent comprehensive study, see Katja Creuz, State Responsibility in the International Legal Order. A Critical Appraisal (CUP 2020).

55 See Jutta Brunnée, 'Procedure and Substance in International Environmental Law' (2020) 405 Recueil des Cours $75,81$.

56 Pamela Ratner et al., 'Setting the Stage for Health Impact Assessment' (1997) 18 Journal of Public Health Policy, $67,68$.

57 Jennifer Mindell et al., 'Improving the use of evidence in health impact assessment' (2010) 88 Bulletin of the World Health Organization 543, 543 .

$5^{8}$ A criticism of the lack of geographical reach when accounting for practice in the use of these tools is found in Lea den Broeder, 'Book review: Kemm J, Parry J, Palmer S (editors). 
spots' have been designed on the basis of epidemiological modelling, showing the role played by different interactions between humans and their ecosystems in increasing the probability of outbreaks. ${ }^{59}$ But none of these tools has advanced to the extent of offering an accurate calculation of the pandemic risks engendered by specific practices, for instance by wildlife trade. Thus, health impact assessments do not have an analytical reach comparable to $\mathrm{EIAs}^{60}$ and certainly lack the same legal pedigree. Though international law on pandemics has a centuries-long history, ${ }^{61}$ medical, epidemiological and public health research cannot offer a full assessment of cross-border risk, since the aforementioned health impact assessments focus on the health of individuals in a specific territory. ${ }^{62}$ It is perhaps why pandemics like CoviD-19 were deemed too abstract a danger in the past, as they were considered "low risk, high impact" events. ${ }^{63}$

Additionally, the numerous drivers of pandemic risk include "micro-events" that may prove to be elusive for probabilistic assessment. ${ }^{64}$ The countless activities that increase pandemic risk cannot be tackled in their entirety. There are simply too many interactions occurring between human and (non-human) animals against the environmental backdrop to account for. In terms of epistemic limitations in understanding pandemic risks, prospective epidemiological modelling studies based on abstract calculations cannot be expected to fulfil a predictive role. ${ }^{65}$ For instance, the North American region was not even

Health Impact Assessment: concepts, theory, techniques, and application. Oxford: Oxford University Press, 2004' (2006) 16 European Journal of Public Health 448.

59 Toph Allen et al., 'Global hotspots and correlates of emerging zoonotic diseases' (2017) 8/1124 Nature Communications, 1, 5-7.

6o Meelan Thondoo and Joyeeta Gupta, 'Health impact assessment legislation in developing countries: A path to sustainable development?' (2020) 30 Review of European, Comparative \& International Environmental Law, 107, 108.

61 The first binding International Sanitary Convention was adopted in 1892 in Venice. Stefania Negri, 'Communicable disease control' in Gian Luca Burci and Brigit Toebes (eds), Research Handbook of Global Health Law (Edward Elgar Publishing 2018) 265-266.

62 Already argued by Anne Steinemann, 'Rethinking human health impact assessment' (2000) 20 Environmental Impact Assessment Review, 627, 628.

63 Bernice Lee, Felix Preston and Gemma Green, 'Preparing for High-impact, Low-probability Events. Lessons from Eyjafjallajökull' (Chatham House Report, January 2012) 2, <https:// www.chathamhouse.org/sites/default/files/public/Research/Energy,\%2oEnvironment \%2oand\%2oDevelopment/ro112_highimpact.pdf >.

64 Mónika Ambrus, Rosemary Rayfuse and Wouter Werner (eds), Risk and the Regulation of Uncertainty in International Law (ouP 2017) 4.

65 On how predicting is not the role of science, but rather to sketch different plausible scenarios, Jacqueline Peel, 'Imagining Unimaginable Climate Futures in International Climate Change Law', in Monika Ambrus, Rosemary Rayfuse and Wouter Werner (eds), Risk and Regulation of Uncertainty in International Law (OUP 2017) 180. 
a "disease hot spot" under any of the existing estimations when the new strain of the H1N1 influenza virus began spreading in $2009 .{ }^{66}$ Instead, projections had placed the highest risk of an influenza pandemic in South Asia, which could possibly take place due to the avian variants (i.e. $\mathrm{H} 5 \mathrm{~N} 1$ ) ${ }^{67}$ It does not mean pre-pandemic estimations were mistaken. Rather, it is a showcase of the difficulties when facing this type of risk in conducting probabilistic calculation of an event which may or may not occur. ${ }^{68}$ Clear and comprehensive explanations of what weight should be provided to concrete scientific evidence in policymaking would help avoid unrealistic expectations.

In a similar fashion to the interface between human and (non-human) animals, the human-environmental constellation is linked to increased pandemic risks, although the links are yet more diffuse. Deforestation, growing urbanization, and global warming all lead to the migration of (non-human) animal species from their natural reservoirs. ${ }^{69}$ This, in turn, increases the chances that disease carriers from the (non-human) animal remit engage in physical contact with humans. Though now mostly of historical relevance, pre-XXI Century pandemics were occasionally caused by cholera, a pathogen circulating in polluted water, among other carriers. ${ }^{70}$ These outbreaks were mostly triggered by poor sanitation conditions and the absence of adequate human waste disposal systems. ${ }^{71}$ The linkages between environmental pollution and hazards to human health stand at the heart of epidemiology's consecration as a specialized field of knowledge. These insights are acknowledged in recent international reports on how to tackle zoonotic risk. ${ }^{72}$

66 Instead, the "hottest" spots for disease outbreaks are found mostly in the African continent and South-East Asia. Allen et al. (n 59).

67 wHo, 'Strengthening Response to Pandemics' (n 33) 6; Lawrence Gostin and Benjamin Berkman, 'Pandemic Influenza: Ethics, Law and the Public's Health' (2007) 50 Administrative Law Review, 121, 123-125.

68 Nita Madhav et al., 'Pandemics: Risks, Impacts, and Mitigation' in Dean Jamison et al. (eds), Disease Control Priorities. Improving Health and Reducing Poverty (The World Bank 2018 $\left.{ }^{3}\right) 316$.

69 Allen et al. (n 59).

70 Richard Evans, 'Epidemics and Revolutions: Cholera in Nineteenth-Century Europe' (1988) 120 Past \& Present, 129.

71 John Snow, a pioneer of modern epidemiology, provided sound evidence on the link between a contaminated water pump and the incidence of cholera cases in London in 1854. His ground-breaking study is published in On the Mode of Communication of Cholera (London, $1855^{2}$ ).

72 Food and Agriculture Organisation (FAO), the World Organisation for Animal Health (OIE) and the wHo, 'Taking a Multisectoral, One Health Approach: A Tripartite Guide to Addressing Zoonotic Diseases in Countries' (Geneva: WHo Press, 2019) 2. 
While research on the 'One Health' approach is growing, ${ }^{73}$ the level of clearcut policy prescriptions is still a work in progress. The limited and uneven progress is possibly related to how pandemics are sporadic, usually timeconstrained events, ${ }^{74}$ as opposed to e.g. certain types of environmental hazards occurring in a continuous manner, like those related to climate change, ${ }^{75}$ allowing for more in-depth risk assessments. The turn towards more holistic approaches of disease outbreaks may provide additional scientific grounds on the types of activities that increase pandemic risks. As argued below, when facing the challenge of dealing with the countless, ubiquitous drivers, a midway compromise can be to devise legal commitments for addressing activities which act as pandemic risk "maximisers". By weighing their influence in probabilistic estimations, enlisting and prioritising the most salient drivers of pandemic risk would be a meaningful contribution to the endeavour. ${ }^{76}$ Otherwise, if future perspectives towards regulation are too broadly framed, it might result in a diffuse allocation of limited resources, leading to ineffective tools prone to flounder when they are needed. As the saying goes, when everything is a priority, nothing is a priority.

\section{From Pandemic Response to Pandemic Risk Reduction}

A core concern of the international community of states is how to ensure persons are protected against global threats that transcend territorial borders. Facing those threats is a task going beyond the remit of any single state. ${ }^{77}$ Cooperation is a normative necessity in so far as no single national political entity has the power to regulate, much less to implement rules far beyond their

73 Anne Peters, 'COVID-19 As a Catalyst for the (Re)Constitutionalisation of International Law: One Health - One Welfare' in Makase Moïse Mbengue and Jean d'Aspremont (eds), International Law and Crisis Narratives (Brill 2021, forthcoming).

74 While there is no conclusive definition of 'pandemic', amongst its denominators within the medical and public health community is its extraordinary nature as triggered, for example, by a novel disease. Morens, Folkers and Fauci (n 14).

75 See recent metadata documenting the impact of human activity on climate change for a span of basically one hundred and seventy years, i.e. from 1850 until 2020, at Intergovernmental Panel on Climate Change, 'Climate Change 2021. The Physical Science Basis. Contribution of Working Group I to the Sixth Assessment Report of the Intergovernmental Panel on Climate Change' [Valérie Masson-Delmotte et al.] (Cambridge University Press, in press) 1-116-1-119.

76 FAO, OIE and WHo (n 72) 39-40.

77 Jan Klabbers, 'The EJIL Foreword: The Transformation of International Organizations Law' (2015) 26 The European Journal of International Law, 9, 24-25. 
territorial jurisdiction. ${ }^{78}$ This is the underlying rationale leading to multiple fields of international law. ${ }^{79}$

Legal obligations enshrined in international law rules ${ }^{80}$ are formulated according to specific conceptions of problems. They often reflect a consensus on shared normative goals. ${ }^{81}$ Thus, legal instruments create expectations that the description of obligations therein will allow for determining compliance or non-compliance, and that there may be consequences in case of the latter. ${ }^{82}$ Behind the conceptions of what needs to be regulated under international law lies an understanding that preventing 83 certain harmful outcomes deriving from actions or omissions attributable ${ }^{84}$ to states, as espoused under the law of international responsibility, is necessary. At the outset, a factual link between state action or omission and an outcome, namely a physical harm, must be identified..$^{85}$ It is not meaningful to create obligations of harm prevention when such causal links are not existent ${ }^{86}$ or, alternatively, not clearly visualised. Therefore, pre-existing factual assessments require input on whether and

78 On the limitations of domestic measures to face pandemics, see the recently published Report of the G2o High Level Independent Panel on Financing the Global Commons for Pandemic Preparedness and Response, 'A Global Deal for our Pandemic Age' (June 2021) 64, $<$ https://www.g2o.org/high-level-independent-panel-urges-the-g2o-to-launch-a-global -deal-to-prevent-catastrophic-costs-of-future-pandemics.html>.

79 Martti Koskenniemi, ILC, 'The Fragmentation of International Law: Difficulties arising from the Diversification and Expansion of International Law' (1 May-9 June and 3 July-11 August 2006) UN Doc A/CN.4/L.682, para. x; Daniel Esty, 'Good Governance at the Supranational Scale: Globalizing Administrative Law' (2006) 115 Yale Law Journal, 1490, 1551 .

8o The distinction between primary and secondary rules is taken from the law of international responsibility. Eric David, 'Primary and Secondary Rules' in James Crawford, Alain Pellet, Simon Olleson and Kate Parlett (eds), The Law of International Responsibility (OUP 2010) 27-32.

81 On the particular role of these sources of law, see James Crawford, Brownlie's Principles of Public International Law (OuP 2019 ${ }^{9}$ ) 18-34.

82 Philip Allott, 'State Responsibility and the Unmaking of International Law' (1988) 29 Harvard International Law Journal, 1, 12.

83 On the evolution of the principle of harm prevention, including its more specific constellation as a rule in environmental law, see Leslie-Anne Duvic-Paoli, The Prevention Principle in International Environmental Law (CUP 2018).

84 Luigi Condorelli and Claus Kress, 'The Rules of Attribution: General Considerations', in James Crawford, Alain Pellet, Simon Olleson and Kate Parlett (eds), The Law of International Responsibility (OUP 2010) 224.

85 A careful distinction is made between 'correlation' and 'causation', as these are not used equally in the legal and the scientific fields.

86 Similarly, see Oscar Schachter, 'The Emergence of International Environmental Law' (1991) 44 Journal of International Affairs, 464. 
how different events are correlated. Scientific research plays a decisive role in this process.

The focus of the current contribution has been the possibility of (future) rules establishing obligations of pandemic prevention, and what the overarching obstacles for their consolidation would be. This goal is linked to the question of to what extent human activity had an influence in the occurrence itself of a pandemic event. In the case of the regulation of events with a "natural" origin, the core understanding is that they would have occurred regardless of human intervention. ${ }^{87} \mathrm{~A}$ closely related, but distinct concept is force majeure as a circumstance precluding wrongfulness due to an unpredictable event. The term refers to facts considered to be either natural or manmade, but which fall beyond the control of a state. ${ }^{88}$ This, however, emerges at the level of a secondary rule on responsibility for internationally wrongful acts. ${ }^{89}$

The language found in several institutional acts opens the possibility to overcome the stark distinction between events with a supposedly natural origin, and those which are manmade. Such is the case, for example, of the United Nations Millennium Declaration, ${ }^{90}$ reinstated by the Hyogo Framework for Action $2005^{-2015^{91}}$ and its successor, the Sendai Framework for Disaster Risk Reduction $2015^{-2030},{ }^{92}$ both developed in the aegis of the United Nations Office for Disaster Risk Reduction. The two instruments affirm the need for states to tackle non-natural drivers of disasters, though they do not list concrete examples. Similarly, a joint report issued by the International Federation of Red Cross and Red Crescent Societies (IFRC) and the United Nations Development Programme (UNDP) in 2014 openly challenged the framing of disasters as exclusively "natural", by considering that human activities can play

\section{$87 \quad$ Ibid., 52.}

88 Sandra Szurek, 'Circumstances precluding Wrongfulness in the ILC Articles on State Responsibility: Force Majeure' in Crawford, Pellet and Parlett (n 83) 477; using earthquakes as an example of events beyond the control of states, ECHR, Özel and Others $v$. Turkey, Judgment (17 November 2015) para. 173.

89 Martins Paparinskis, 'The Once and Future Law of State Responsibility' (2020) 114 American Journal of International Law, 618, 618-626.

90 United Nations General Assembly, 'United Nations Millennium Declaration', Resolution 55/2, Fifty-fifth session, 18 September 200o, A/REs/55/2, para. 23.

$91 \quad$ United Nations Office for Disaster Risk Reduction, 'Hyogo Framework for Action 20052015. Building the Resilience of Nations and Communities to Disasters', World Conference on Disaster Reduction (A/CONF.206/6).

92 United Nations Office for Disaster Risk Reduction, 'Sendai Framework for Disaster Risk Reduction 2015-2030' (18 March 2015) UN Doc A/CONF.224/CRP.1. Adopted by UNGA Res 69/283 (23 June 2015) UN Doc A/REs/69/283. 
a direct role in triggering their devastating impact. ${ }^{93}$ It is also worth clarifying that single events may have both non-human and human drivers. What these documents show as well, is how one single event can blur the line between the "natural" and the manmade.

A different matter in the application of international law consists of ascertaining the factual links leading to specific harmful outcomes where human activity plays a direct role, i.e. "manmade", and those where it hasn't, deemed to be "natural" ${ }^{94}$ Being a social construct, the distinction is an artificial one. ${ }^{95}$ The negative cross-border impact of human activities is subject to both rules and principles of international law, as recognised by both the ILC in its Draft Articles on Prevention on Transboundary Harm from Hazardous Activities, ${ }^{96}$ and by the International Court of Justice (ICJ) in its case law. Behind it lies the consideration that states, as the main rights- and obligation-holders, should refrain not only from conducting acts that will harm other states, but also from knowingly allowing acts in their territories that may be 'contrary to the rights of other states. ${ }^{97}$

The no-harm rule has been developed most thoroughly in the field of international environmental law. ${ }^{98}$ On the basis of the rule's recognition as customary international law, states parties should refrain from conducting acts with a negative transboundary impact, particularly those of a physical nature. ${ }^{99}$ The landmark Trail Smelter dispute arguably triggered the gradual consolidation of more specific obligations deriving from the no-harm principle, especially pertaining to activities causing transboundary environmental damage. ${ }^{100}$ Throughout the course of several decades, the meaning of the

93 IFRC and UNDP, 'Effective law and regulation for disaster risk reduction: a multi-country report. Summary' (New York 2014) 2.

94 The term force majeure is often used to refer to acts beyond human control. For its role in international law, see Sandra Szurek, 'Circumstances Precluding Wrongfulness in the ILC Articles on State Responsibility: Force Majeure' in James Crawford, Alain Pellet and Simon Olleson (eds) The Law of International Responsibility (oup 2013) 477.

95 Daniel Farber, 'Disaster Law in the Anthropocene', in Peel and Fisher (eds) (n 7) 49-50.

96 ILC, 'Draft Articles on Prevention of Transboundary Harm from Hazardous Activities (with Commentaries)' (2001) II:2 Yearbook of the International Law Commission, 148.

97 ICJ, Corfu Channel (United Kingdom v. Albania) (Merits) ICJ Rep 1949, 22.

98 ICJ, Pulp Mills on the River Uruguay (Argentina v. Uruguay) (Merits) ICJ Rep 2010 (I) 56, para. 101.

99 ILC, Draft Articles on Prevention of Transboundary Harm, Articles 1 and 2; see also Duvic -Paoli (n 83) 235.

100 While the literature on the subject is vast, for a mere glimpse: Arthur Kuhn, 'The Trail Smelter Arbitration: United States and Canada' (1941) 35 American Journal of International Law 665, 665-666; Alfred Rubin, 'Pollution by Analogy: The Trail Smelter Arbitration' (1971) 5o Oregon Law Review 259, 259-282. 
no-harm principle evolved in its application to specific settings. A detailed account of this evolution is beyond the scope of this article. Suffice it to say that, beyond the Trail Smelter dispute, more recent judicial decisions such as Pulp Mills and Costa Rica v. Nicaragua have delved deeper in the question of how to frame states' due diligence obligations in order to prevent cross-border environmental or other harm. Besides the ICJ, other international adjudicative bodies ${ }^{101}$ have considered harm prevention to be a part of customary international law as well. A key consideration is how to infer that a state should have known in advance that a certain act would lead to a specific harmful outcome. Therefore, on the basis of the no-harm rule, states are now subjected to more concrete obligations of conducting EIAs in the case of human activities that may have a 'significant adverse impact in a transboundary context'. 102

The proponents of a 'deep prevention' of pandemics argue that the only way to reduce the risk thereof is to tackle the human - (non-human) animal environmental interface in a holistic matter. ${ }^{103}$ Tailoring prevention involves identifying which human activities increase the level of hazard. Taking into consideration the countless micro-events that can lead to pandemics, devising an exhaustive list would be mired with pitfalls, and their full prohibition seems to be a tall order ${ }^{104}$ due to both factual (what exactly should be prohibited?) and political (how many states would agree to cede their sovereign rights and to what extent?) difficulties. Instead, pandemic risk reduction obligations can be approached as a matter of degree, rather than in absolute terms. The purpose would be to tackle the complex set of events leading to the global spread of a disease among humans to the largest extent possible. Focusing on prevention, moreover, would allow for shifting the legal responsibility of pandemic to states either for their occurrence as such, or rather in light of their harmful effects. In line with the literature on the regulation of risk, a preventive approach should not be understood as being directly tagged to an outcome. ${ }^{105}$

101 See the issue of prevention as the basis for claimant's case in Permanent Court of Arbitration, Indus Waters Kishenganga (Pakistan v India), 2011-01, Final Award (20 December 2013) para. 87.

102 ICJ (n 53) para. 104.

103 Viñuales, Moon, Le Moli and Burci (n 4).

104 Jaye Ellis, 'Liabilities for International Environmental Harm' (2018) Oxford Bibliographies Online.

105 Heike Krieger and Anne Peters, 'Due diligence and structural change in the international legal order', in Heike Krieger, Anne Peters and Leonhard Kreuzer (eds) Due Diligence in the International Legal Order (OUP 2020) 351-39o. 
Otherwise, it would subject the criteria for a legal instrument's success to the occurrence or not of certain events.

Insights from the field of international environmental law can contribute to offset the potential limitations of pandemic risk reduction obligations. Resorting to the concept of prevention in international environmental law on the basis of the Rio de Janeiro Declaration of $1992^{106}$ would be illustrative. Whereas so far the harm prevention principle has played a role mostly in disputes due to environmental harm, its more general components can be explored for other issues that are transboundary in nature. Proactive perspectives involve states' adoption of measures in the face of activities known to cause harm. ${ }^{107}$ The cross-border spread of disease lends itself to this type of scrutiny.

Also in the environmental field, there is a recognition that in some scenarios risk can only be reduced, not eliminated. ${ }^{108}$ As espoused at the Governing Council of the United Nations Environmental Programme, when handling shared natural resources, states should avoid 'to the maximum extent possible and (...) reduce to the minimum extent possible' the negative extraterritorial effects of the use of shared natural resources, including when this may endanger the health of the population in other jurisdictions. ${ }^{109}$ Similarly, comprehensive international regulation aimed at fully neutralising any and all pandemic risks would be a chimera. The potential of eradicating all new pathogens that might circulate among humans is not realistic. Recent studies show how possibly nonillions ${ }^{110}$ viral particles are present on Earth. ${ }^{111}$ These are but one potential source or vector of infectious diseases; potential pathogens include other microorganisms like bacteria or fungi. Such information should lead to a realisation that pathogens are, actually, an inherent component of our ecosystem.

106 Particularly, Principle 15 states 'lack of full scientific certainty shall not be used as a reason for postponing cost-effective measures to prevent environmental degradation' (emphasis added). Rio de Janeiro Declaration on Environment and Development (14 June 1992) 31 International Legal Materials, 876 .

107 See Duvic-Paoli (n 83) 200.

108 ECHR, Özel and Others v. Turkey (n 88).

109 UNep, 'Environmental Law: Guidelines and Principles. Shared Natural Resources', Principle 2 (Nairobi, 1978) 2.

110 To give a basic idea, whereas millions are expressed in the short scale as $10^{6}$, nonillions are expressed as $10^{30}$.

111 Amber Dance, 'The incredible diversity of viruses' (2021) 595 Nature 22, 22-25. 
Pandemic risk reduction requires having the capacity to detect and assess the emergence of a new disease to begin with. ${ }^{112}$ A deeper prevention could be underpinned by the legal obligation to enhance healthcare core capacities, foreseen in Article 5 of the IHR (2005). A statutory period of five years was granted, with the possibility to request two extensions of two years each for a grand total of nine years. Given the complexities inherent to the fulfilment of this obligation, it is not a one-off event, but rather a continuous process. ${ }^{113}$ In order to prevent punishing countries with lower capacities in these fields, the IHR provided common but differentiated obligations, expressed in distinct periods for reporting the successful development of minimum core capacities. Just before the CoviD-19 pandemic, the insufficient fulfilment of these obligations was a source of preoccupation. ${ }^{114}$ In order to avoid obligations that are more punitive towards countries with fewer resources, a differentiated approach towards pandemic risk reduction will be required. It will likely lead to years of careful and judicious negotiations, where each state would make its own claim at receiving a preferential treatment.

The gaps described so far underscore some of the inherent limits in the effective regulation at the international level of pandemic risk. Several of these limits may prove to be insurmountable in the near future. For instance, conducting research in order to map the countless human interactions with non-human animals and the environment that increase pandemic risk is bound to be a time-consuming activity. But that does not suggest there is nothing to be done. To the contrary, it is possible to design specific policies aimed at filling the epistemic gap, which will in turn help in devising a legal framework that accurately grasps underlying factual circumstances.

112 This had been argued even before the current IHR (2005). Allyn Taylor, 'Controlling the Global Spread of Infectious Diseases: Toward a Reinforced Role for the International Health Regulations' (1997) 33 Houston Law Review, 1327, 1361.

113 wно, 'Report of the Review Committee on Second Extensions for Establishing National Public Health Capacities and on IHR Implementation' (16 January 2015) EB136/22 Add.1, para. $6<$ https://apps.who.int/gb/ebwha/pdf_files/EB136/B136_22Add1-en.pdf>.

114 Some progress in surveillance capacities had been reported by states until 2019. WHO, Annual report on the implementation of the International Health Regulations (2005), A72/8, 4 April 2019, paras. 8-11. 
The first step in framing legal obligations to regulate pandemic risk is to identify existing activities that maximise or enhance the risk of a pandemic event. This would allow for setting the scene in order to explore which regulatory options are available, especially with a view to measures taken at the domestic level. ${ }^{115}$ Past studies have observed and cross-referenced the extent to which different variables, like population density, biological i.e. mammal biodiversity, and climate may increase or decrease the likelihood of pandemic events. ${ }^{116}$ A recent scientific assessment by multiple stakeholders, including the United Nations Environmental Programme (UNEP), identifies seven anthropogenic i.e. human-related drivers of zoonotic hazards, including the numerous elements of animal product consumption, agricultural practices, travel and transportation, and climate change. ${ }^{117}$ These results are not mathematically exact in attributing weight to each of the drivers. In the current stage of scientific research, a fully calibrated mapping of the impact of human activities in increasing pandemic risk may be too tall of an order, considering inter alia its multi-level dimension encompassing international, regional and national factors. ${ }^{118}$

Two relatively modest steps can already be taken. Firstly, increasing knowledge may help with understanding the prevailing degree of uncertainty in enlisting the key drivers of pandemic risk. As argued below in the conclusion, a gradual advancement towards filling the existing epistemic gaps would lead to a clearer understanding of what is feasible. Under a 'One Health' perspective, the process of increasing the knowledge on pandemic risks should include a more in-depth mapping of relevant stakeholders, understood as individuals or groups that can play a role in mitigating the risks of disease-related events, notably through zoonotic spill overs. ${ }^{119}$

A fully exhaustive scrutiny is not necessary for devising criteria for legal responsibility. The process of enumerating activities need not be undertaken

115 This goal is explicitly mentioned in the recent report by the Institut de Droit International (n 13) paras. 110-117. However, the report does not go into specifics of which activities would be included as part of preventive legal obligations of states in the aegis of pandemics.

116 Allen et al (n 59) 3-7.

117 UNeP/International Livestock Research Institute, see Preventing the Next Pandemic. Zoonotic disease and how to break the chain of transmission (n 25) 15-17.

118 On a similar challenge in the environmental field, see Alejandro Camacho, 'Adapting Governance to Climate Change: Managing Uncertainty Through a Learning Infrastructure' (2009) 59/1 Emory Law Journal, 1, 10.

119 Such a perspective is framed, in basic terms, in the ongoing tripartite collaboration between the WHO, the OIE, and the FAO (n 76 ) 38-39. 
in a legally binding instrument. Instead, under a dynamic perspective it may be the outcome of ulterior institutional processes. ${ }^{20}$ Similar undertakings exist in the Intergovernmental Panel on Climate Change. Its standards, while not legally binding, contribute to shaping the interpretation of states' obligations within the purview of the United Nations Framework Convention on Climate Change. They may later be cited as grounds for holding states responsible, particularly in domestic judicial proceedings. ${ }^{121}$

Once the initial scientific and political consensus is achieved for pinpointing activities that are known to increase the likelihood of disease outbreaks, the risks posed by those activities should be assessed in a continuous manner, as changing circumstances may alter calculations. For instance, the detection of the spread of new pathogens may occur at any moment, requiring constant on-the-ground surveillance. Consequently, enhancing the IHR (2005)'s surveillance obligations in order to include human activities that are known to maximise the risk of communicable disease outbreaks could thus be a stepping stone towards proactive international law in the field. ${ }^{122}$ In this vein, a recent report by an IHR Review Committee summoned to evaluate the response by the WHO and Member States to the COVID-19 pandemic underscored how the current system is heavily reliant upon so-called National Focal Points. ${ }^{123}$ The latter are designated authorities meant to maintain a constant channel of communication with the wHO, in case a disease-related event must be notified. ${ }^{124}$ Problems arise when these designated authorities do not have sufficient competences to tackle the multidimensional components of a healthcare system, which sets the basis for disease surveillance at the national level. Seeing how insufficient capacities in several Member States considerably undermine the functioning of the IH R (2005), ${ }^{125}$ blind spots emerge in the

120 On how the dynamic evolution of rules and standards related to liability in the field of international disaster law, see Michael Faure, 'Liability and Compensation as Instruments of Disaster Risk Reduction?', in Peel and Fisher (eds) (n 7) 286-287.

121 Whether domestic judges may hold national authorities responsible for failing to uphold international law obligations depends on how the national legal system incorporates these norms. For instance, see the most recent first instance judgment in the Netherlands against Shell, The Hague District Court, Milieudefensie et al. v. Royal Dutch Shell plc. (26 May 2021) C/o9/571932 / HA ZA 19-379 (English Version) http:// climatecasechart.com/climate-change-litigation/wp-content/uploads/sites/16/non-us -case-documents/2021/20210526_8918_judgment-2.pdf.

122 See Burci and Eccleston-Turner (n 1$)$.

123 See wно, Report of the Review Committee on the Functioning of the International Health Regulations (2005) during the covid-19 Response, A74/9 Add.1, 5 May 2021, 22-23.

124 In accordance with Article 5 IHR (2005).

125 Bartolini (n 37) 241-245; Institut de Droit International (n 13) paras. 104-105. 
identification of new and re-emerging health threats. Addressing such blind spots would be necessary in order to more accurately visualise the constellation of activities that increase the likelihood of a pandemic risk. Cross-fertilization with other fields of law would be necessary, given the multitude of activities included in that operation. ${ }^{126}$ To mention one example, mapping the multiple components of supply chains in the cross-border wildlife trade could contribute towards fulfilling that goal. ${ }^{127}$

International law obligations of pandemic risk reduction would require a degree of specificity. At the very least, they should allow for identifying states' activities and setting the bases for determining when there is a legal breach. ${ }^{128}$ Considering the impossibility to eliminate pandemic risk altogether, the criteria for legal responsibility can be detached from the question of whether an event has occurred or not. ${ }^{129}$ In line with the standards on due diligence, future steps for fostering the goals of pandemic deep prevention can be based on a results-independent yardstick. ${ }^{130}$ What is key for allocating responsibility would not be whether acts or omissions lead to a pandemic, but rather whether sufficient steps are taken for reducing the risk. ${ }^{131}$ At first glance, it may seem problematic to frame risk reduction obligations as results-independent, since it might convey the notion that the regulatory approach is not conducive to positive outcomes. ${ }^{132}$ Yet, as the proponents of pandemic 'deep prevention' strategies have explained, devising legal obligations should strive towards steering state behaviour away from practices that are known to increase the likelihood of health hazards. ${ }^{133}$ The understanding of the determinants of

126 Charlotte Blattner, Protecting Animals Within and Across Borders: Extraterritorial Jurisdiction and the Challenges of Globalisation (OUP 2019) 156-16o.

127 On suggestions to reform, or at least reinterpret the Convention on International Trade in Endangered Species of Wild Fauna and Flora (CITES) to this effect, Amanda Whitford, 'COVID-19 and Wildlife Farming in China: Legislating to Protect Wild Animal Health and Welfare in the Wake of a Global Pandemic' (2021) 33 Journal of Environmental Law, 57.

128 Pierre-Marie Dupuy, 'Back to the Future of a Multilateral Dimension of the Law of State Responsibility for Breaches of "Obligations Owed to International Community as a Whole"' (2012) 23 European Journal of International Law, 1059.

129 In a similar fashion, again, to international environmental law, see Brunnée (n 55) 162.

130 See Krieger and Peters (n 105).

131 Pierre-Marie Dupuy, 'Reviewing the Difficulties of Codification: On Ago's Classification of Obligations of Means and Obligations of Result in Relation to State Responsibility' (1999) 1o European Journal of International Law, 371, 379; Robert Barnidge, 'The Due Diligence Principle under International Law' (2005) 8 International Community Law Review, 81, 112.

132 A similar concern has been expressed in Marie Aronsson-Storrier, 'Beyond Early Warning Systems: Querying the Relationship Between International Law and Disaster Risk (Reduction)' (2018) 1 Yearbook of International Disaster Law, 51, 61-62.

133 See Viñuales, Moon, Le Moli and Burci (n 4). 
health should go beyond the strictly-speaking biomedical perspective, instead reaching for the non-medical drivers that need to be tackled for an effective pandemic risk reduction. ${ }^{134}$ Multiple human activities driven by economic concerns are directly at stake. Thus, the only way to ensure that more holistic regulatory options are legally sound is to engage in a cross-cutting legal study of the multiple fields of international law involved in proactive obligations for states of pandemic risk reduction. Both international environmental law and international trade law are standout examples of areas where a harmonised regulation of pandemic risk "maximisers" is required, since the potential restriction or even prohibition of certain activities, like wildlife trade, may require expanding the current reach of CITES. ${ }^{135}$ Furthermore, the litmus test for any and all commitments by states in pandemic risk reduction will lie in the implementation of measures at the domestic level. ${ }^{136}$ Certainly, ascertaining the domestic implementation of comprehensive obligations would involve onerous fact-finding, the cost of which should not be underestimated. It will be dependent upon the willingness of national authorities to actually engage in multidimensional processes of compliance, which is by no means a minor burden.

In any case, when facing the question of which one of the pandemic risk "maximisers" ought to be subjected to a more stringent regulation, guaranteeing constant monitoring will be required. The standing surveillance of the "maximisers" of pandemic risks should be taken into account in any and all incoming debates regarding new international law instruments in the field of pandemics. Similar steps have been devised in the area of disaster risk reduction. Article 9 of the ILC's Draft Articles on the Protection of Persons in Disasters ${ }^{137}$ enshrines prevention obligations for states to be effectuated through the collection and dissemination of disaster risk-related information, as well as to institute early warning systems. The latter require a constant operation, since obligations in the area have been understood to be applicable to all states and not only those experiencing disasters at a given moment. ${ }^{138}$ States' obligations in this matter are further shaped by the aforementioned Sendai Framework for Disaster Risk Reduction 2015-2030, which fosters the

\footnotetext{
134 Marco Toscano-Rivalta, 'Disaster risk reduction in light of the COVID-19 crisis: Policy and legal considerations' (2O2O) 70 QIL, Zoom-out, 37, 55 .

135 Whitford (n 127) 75-79.

136 Draft Article 9, commentary, para. 8.

137 ILC, 'Draft articles on the protection of persons in the event of disasters', adopted at the sixty-eight session (2016) A/71/10, para. 48.

138 As explained in Draft Article 9, commentary, para. 8.
} 
streamlining of processes for identifying risks, monitor them and issuing early warnings to the community at large. ${ }^{139}$

The premise of constant surveillance espoused in disaster risk reduction obligations could be applied in the area of pandemics, whilst tailoring them to the epistemic peculiarities. One possibility is to streamline existing surveillance mechanisms currently divided between human and non-human diseases and expand their scope. In this sense, an initiative was launched by a tripartite collaboration between the WHO, the OIE and the FAO in order to harmonise the warning systems deriving from the IHR (2005) for humans, and the Terrestrial Animal Health Code for (non-human) animals. ${ }^{140}$ On the basis of notification by states, the collaboration strives to monitor health threats posed by communicable disease outbreaks as part of a broader interface. The undertaking has further evolved in the area of Antimicrobial Resistance (AMR), where there is a more developed setting with a standing Tripartite Secretariat hosted by the WH $0 .{ }^{141}$ Therefore, even if prohibition may not be readily available, a more far-reaching disease surveillance system could not only bridge the human - (non-human) animal - environmental interface, but also be expanded to include the multiple "maximisers" of risk, such as instances of trade in wild animals. As argued previously in the field of disaster risk reduction, any effective surveillance and warning system for pandemics would need to be more expansive in order to tackle more systemic determinants ${ }^{142}$ not limited to the early detection of a new or re-emerging disease.

If obligations of pandemic risk prevention were to be established, subsequent doctrinal difficulties would emerge. The legal consequences of failing to uphold prevention obligations would need to be assessed under existing criteria of the responsibility of states for internationally wrongful acts, as fostered by the ILC's corresponding articles. Clarity would be needed on how to interpret secondary rules ${ }^{143}$ under the law of international responsibility in cases

139 United Nations Office for Disaster Risk Reduction (n 92).

140 FAO, OIE and WHO, 'The FAO-OIE-WHO Collaboration: Sharing responsibilities and coordinating global activities to address health risks at the animal-human-ecosystems interfaces. A Tripartite Concept Note' (April 2010) 8-9, <https://www.who.int/foodsafety/ zoonoses/final_concept_note_Hanoi.pdf>.

141 Tripartite Joint Secretariat on Antimicrobial Resistance. Terms of Reference, October 2019, <https://www.who.int/docs/default-source/antimicrobial-resistance/amr-gcp-tjs/tjs -tor-final-october-2019.pdf?sfvrsn=bbd8a3fe_o $>$.

142 Following Aronsson-Storrier ( $\left.\mathrm{n}_{132}\right) 69$.

143 The distinction between primary and secondary rules is taken from the law of international responsibility. Eric David, 'Primary and Secondary Rules' in James Crawford, Alain Pellet, Simon Olleson and Kate Parlett (eds), The Law of International Responsibility (OUP 2010) 27-32. 
of the potential breach of obligations by states. A different but related question is whether the doctrine of state responsibility for internationally wrongful acts is well-suited to provide the required incentives for devising the obligations in the first place, and for complying with them afterwards. ${ }^{144}$

The current analysis focused on highlighting some of the prevailing epistemic gaps in the accurate assessment of pandemic risks, as well as its relationship with a potential legal regime aimed at prevention instead of merely response. The question of how to tailor responsibilities in the area of the cross-border spread of disease can, and should, strive towards overcoming purely reactive approaches. Only by knowing what is feasible to prevent can obligations of pandemic risk reduction be framed in a meaningful manner.

As argued in section 2, looking beyond the anthropocentric perspective is necessary for further unravelling the countless micro-events that contribute to the likelihood of disease outbreaks with a potential for cross-border spread. While not all of them may be susceptible of regulation at the international level, identifying human actions that represent "maximisers" of risk and weighing their role in enhancing the likelihood of triggering pandemic events can be a major step forward. Consequently, by way of a global public policy, both states and international organizations should increase investment in conducting research that is not necessarily oriented towards immediate human concerns. ${ }^{145}$ Rather, under a holistic perspective, deeper investigations of ecosystems ${ }^{146}$ as bona fide objects of study can help identify at which point in the human - (non-human) animals - environment interface do human interventions begin to play a role in maximizing pandemic risk.

The intergovernmental discussions after the Covid-19 pandemic will require accurately grasping factual complexities inherent to pandemic risks. Better mapping the multiple human acts leading to an increase of the level of threat posed by new and re-emerging communicable diseases would be a meaningful step forward. The only way to ensure this is through the inclusion of insights from medicine, epidemiology and virology in future processes of

144 On the formulation of incentives for fostering compliance with international law, see Anne van Aaken and Betül Simsek, 'Rewarding in International Law' (2021) 115 American Journal of International Law, 195, 199-203.

145 Roeder, Mariner and Kock (n 20) 10.

146 Following Guillaume Futhazar, 'The Normative Nature of the Ecosystem Approach: A Mediterranean Case Study' (2021) 10 Transnational Environmental Law, 109, 110. 
international lawmaking related to pandemic risks. Policy- and lawmakers ought to keep in mind that these are not scientific disciplines capable of providing mathematically exact answers to multidimensional problems. Despite this fact, or rather because of it, robust strategies for overcoming science denialism in decision-making are needed. ${ }^{147}$ Whatever legal proposals emerge in the wake of the devastating COVID-19 pandemic, further tackling the existing epistemic gaps in our knowledge of the drivers of pandemic risk is the only purposeful path forward.

147 Independent Panel for Pandemic Preparedness and Response (n 1) 33. 